Vol. XXIII No 12017

\title{
BREXIT - MAJOR CONSEQUENCES ON THE PROCESS OF EUROPEAN MILITARY INTEGRATION?
}

\author{
Marius PRICOPI \\ “Nicolae Bălcescu" Land Forces Academy, Sibiu, Romania \\ pricopimarius@yahoo.com
}

\begin{abstract}
The United Kingdom's choice to withdraw from the European Union (Brexit) took many by surprise, including a good part of the „Leave” voters. The repercussions of this vote are in full display and affect each and every area of the community life. Considering different indicators (such as the number of troops deployed by the United Kingdom to military operations conducted by the European Union or the British contributions to the Battlegroups), in this paper we submit to analysis the United Kingdom's stance in the process of military integration within the European Union in the period before the Brexit Referendum (2011-2015); we mainly argue that - although regrettable - Brexit will not significantly affect the day-to-day activities and projects conducted within the Common Security and Defence Policy.
\end{abstract}

Keywords: Brexit, common defence, European Union, military integration, United Kingdom

\section{Introduction}

Many agree that, following the June 2016 referendum in the United Kingdom (UK), this country's withdrawal from the European Union (EU) is just a matter of time. The Brexit, either a „soft” or a „hard” one, is expected to impact all areas of cooperation and integration within the EU, including the defence area.

Yet regarding this aspect of defence, it is well known the fact that the UK has never truly been an active sponsor of the military integration process under the auspices of the EU - opting, instead, for a more substantial contribution within the NorthAtlantic Alliance (NATO) and a closer cooperation with its long-standing transAtlantic partner (the United States).

Therefore, in the following we argue that, unlike other trademarks of the European Union (such as the four fundamental freedoms), the military integration process will not be severely affected by Brexit; on the contrary, the absence of the United Kingdom from the decision structures of the European Union may actually put back on the table the possibility of a functional and credible European common defence.

\section{Method}

In writing this paper, we applied in an extensive manner the case study method, as described in a book edited by Detlef Sprinz and Yael Wolinsky-Nahmias and published at the University of Michigan Press [1].

\section{UK's added value to the European military integration process}

In the years before the Brexit Referendum, UK supported the military integration process within the EU in the following two ways: through its considerable military expenditures and through the 
Europeanisation of the Operational Headquarters in Northwood.

Thus, in 2015 the military expenditures of UK rose to 36,445 billion pounds $(59,730$ billion US dollars), representing exactly $2 \%$ of the country's Gross Domestic Product (GDP) [2]. UK was, therefore, one of the four EU countries (along with Greece,
Poland and Estonia) who met the $2 \%$ of the GDP defence spending target [3].

Actually, UK's defence budget alone translated into no less than $23 \%$ of the total defence spending by all European countries (Figure 1).

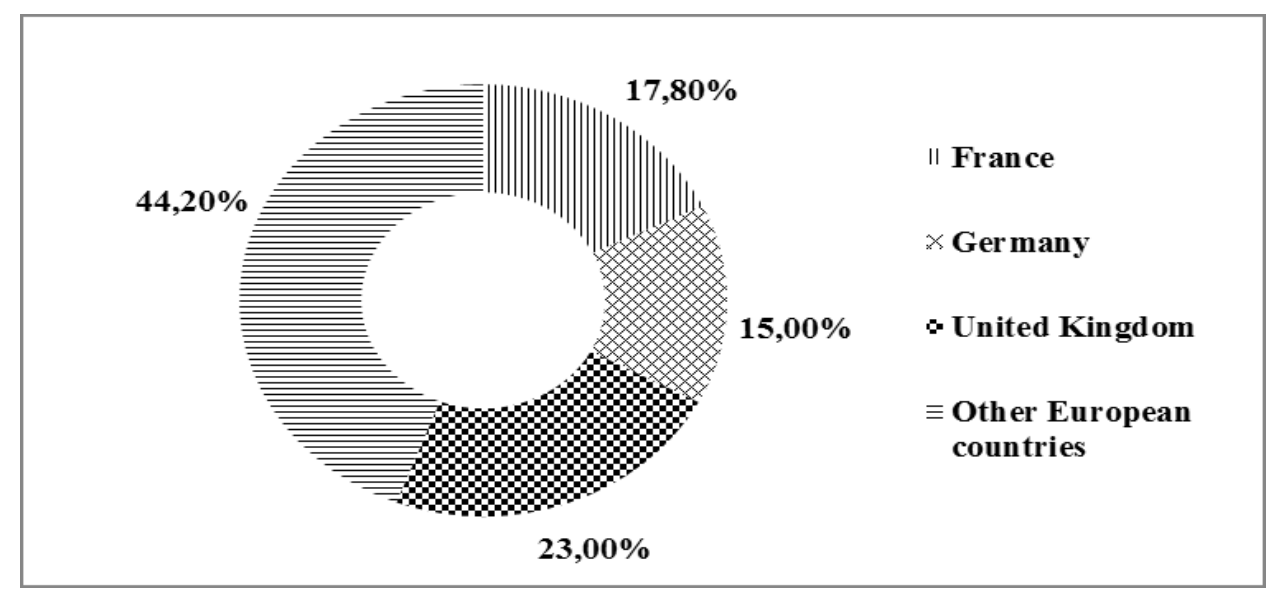

Figure 1: National Defence Expenditures in Europe in 2015 (one year before the Brexit Referendum) [4]

Then, it is important to mention that UK is one of the $5 \mathrm{EU}$ member states who hosts on its national territory an EU Operational Headquarters (the other 4 countries are: France, Germany, Greece and Italy). The British Headquarters is located at Northwood, and it is currently employed for conducting the military operation EU NAVFOR Atalanta, which aims to boost the maritime security on the coast of Somalia. Following Brexit, it is unclear what will happen with this Headquarters, or (if the case) from where will EU NAVFOR Atalanta be conducted in the future.

\section{UK's not so spectacular stance within the European military integration process}

On the other hand, we appreciate UK's performance within the European military integration process prior to the Brexit
Referendum as a modest one, when referring to the following aspects: UK's contribution with troops to the main ongoing military land operations of the EU, UK's sharing of military facilities for common training and UK's contribution to the EU Battlegroups.

First of all, UK's refrain from the European military integration process is underlined by its rather modest contribution to the main three on-going military land operations conducted by the EU (EUFOR Althea, EUTM Mali and EUTM Somalia). As can be seen in Table 1, in 2015 UK contributed with approximately $5 \%$ of the total number of subscribed troops to operations EUFOR Althea, respectively EUTM Mali; the percentage in the case of EUTM Somalia is even lower, revolving around 2,5\%. 
Table 1: Troops subscribed by UK to the main on-going EU military land operations in 2015 (one year before the Brexit Referendum) [5]

\begin{tabular}{|l|c|c|c|}
\hline & $\begin{array}{c}\text { Total no. of } \\
\text { subscribed troops }\end{array}$ & $\begin{array}{c}\text { Troops } \\
\text { subscribed by UK } \\
\text { (no.) }\end{array}$ & $\begin{array}{c}\text { Troops subscribed } \\
\text { by UK (percentage } \\
\text { of total no. of } \\
\text { troops) }\end{array}$ \\
\hline EUFOR Althea & 600 & 31 & $5,15 \%$ \\
\hline EUTM Mali & 506 & 26 & $5,13 \%$ \\
\hline EUTM Somalia & 195 & 5 & $2,56 \%$ \\
\hline
\end{tabular}

Therefore, although the UK is involved in numerous operations around the world, either under the auspices of NATO or as part of multinational coalitions, the British contributions to the EU military land operations have not been very generous. By comparison, for example, in the same year (2015) Germany deployed no less than 209 troops in EUTM Mali only.

Second of all, when discussing shared military facilities, UK's performance before the Brexit Referendum was also a modest one. According to documents made available by the European Union External Action Service (the diplomatic corps of the EU) [6], UK shared with the other member states only 3 facilities for common military training. Other countries have been more generous with their own training facilities; for example, France shared 10 facilities, Romania and Sweden - 13, Italy - 19, while Spain lead the top, with no les then 22 military facilities shared for common military training.

To offer the entire picture, out of the total 113 shared military facilities, only 3 belonged to the UK (less than 3\%). Considering, again, UK's defence budget and the size of its armed forces, we can definitely affirm that the contribution is a modest one.

Third of all, we also analysed data concerning UK's contribution to the EU Battlegroups. In the last 5 years before the Brexit Referendum (2011-2015), UK subscribed troops and military capabilities only once to these Battlegroups (Table 2).
Table 2: Member states' contribution to the EU Battlegroups between 2011-2015 (last 5 years before the Brexit Referendum) [7]

\begin{tabular}{|l|c|}
\hline Country & $\begin{array}{c}\text { No. of } \\
\text { contributions }\end{array}$ \\
\hline Austria & 2 \\
\hline Belgium & 2 \\
\hline Bulgaria & 2 \\
\hline Czech Republic & 1 \\
\hline Cyprus & 2 \\
\hline Croatia & 0 \\
\hline Denmark & 0 \\
\hline Estonia & 2 \\
\hline Finland & 3 \\
\hline France & 4 \\
\hline Germany & 4 \\
\hline Greece & 3 \\
\hline Hungary & 1 \\
\hline Ireland & 2 \\
\hline Italy & 3 \\
\hline Latvia & 2 \\
\hline Lithuania & 3 \\
\hline Luxemburg & 2 \\
\hline Malta & 0 \\
\hline Netherlands & 2 \\
\hline Poland & 1 \\
\hline Portugal & 2 \\
\hline Romania & 2 \\
\hline Slovakia & 0 \\
\hline Slovenia & 1 \\
\hline Spain & 3 \\
\hline Sweden & $\mathbf{1}$ \\
\hline United Kingdom & \\
\hline
\end{tabular}

But in the case of its main counterparts in the EU, the situation is different: France and Germany contributed, each, to no less than 4 Battlegroups during the same period; 
Finland, Greece, Italy, Lithuania, Spain and Sweden had 3 contributions each, while even considerably smaller countries than the UK had higher contributions (Austria, Cyprus, Estonia or Luxembourg).

\section{Conclusions}

The United Kingdom's choice to withdraw from the European Union has been a crucial moment for the European integration process. But regarding the military integration process - as the data analysed in this paper demonstrate - the consequences have a more significant impact on the grand strategy and the future of the EU's common defence, and a rather low impact on the operational conduct of the day-to-day projects and activities.

Indeed, the UK had the highest military expenditures of all the EU member states, and was one of the five members which hosted an EU Operational Headquarters on its territory (at Northwood).

But then again, financial resources have never been an issue in the process of UK's military integration in the EU; what the UK lacked in order to be more active within the EU's common defence were not the money (as is, unfortunately, the case of other member states), but the consensus and the political will of the British leadership.

Therefore, despite the impressive defence budget and the high number of active military personnel, in the year before the Brexit Referendum, UK's contribution with troops to the main on-going military land operations of the EU revolved around 5\% of the total number of subscribed troops; also, out of the 113 shared military facilities for common training within the EU, only 3 belonged to the UK; and finally, in the 5 years before the Brexit Referendum, the British contributed only once to the EU Battlegroups, whereas countries like France and Germany had, for the same period, no less than 4 contributions.

To conclude, we consider that Brexit will not disrupt the European military integration process; on the opposite, it may actually boost it. While the UK will probably continue to exert its influence as an important member of NATO, the EU will finally have the long awaited opportunity to deepen its military integration and enhance its (extensively criticized) Common Security and Defence Policy.

\section{Acknowledgment}

This paper has been elaborated during the sustainability period of the project entitled

„Horizon 2020 - Doctoral and Postdoctoral Studies: Promoting the National Interest through Excellence, Competitiveness and Responsibility in the Field of Romanian Fundamental and Applied Scientific Research", contract number POSDRU/159/1.5/S/140106. This project was co-financed by European Social Fund through Sectoral Operational Programme for Human Resources Development 2007-2013. Investing in people!

\section{References}

[1] Detlef Sprinz (Ed.) and Yael Wolinsky-Nahmias (Ed.), Models, Numbers and Cases, University of Michigan Press, 2004.

[2] Stockholm International Peace Research Institute, SIPRI Military Expenditure Database, https://www.sipri.org/databases/milex, accessed on 1 March 2017.

[3] International Institute for Strategic Studies, The Military Balance - 2016, Routledge, 2016, p. 20.

[4] International Institute for Strategic Studies, The Military Balance - 2016, Routledge, 2016, p. 62. 
[5] International Institute for Strategic Studies, The Military Balance - 2016, Routledge, 2016, pp. 155-156 and p. 103; European Union External Action Service, EU Military Operation in Bosnia and Herzegovina, http://eeas.europa.eu/archives/csdp/missionsand-operations/althea-bih/pdf/factsheet_eufor_althea_en.pdf, accessed on 7 March 2017; Ibidem, EU Training Mission in Mali, http://www.eeas.europa.eu/archives/docs/csdp/missions-and-operations/eutmmali/pdf/factsheet_eutm_mali_en.pdf, accessed on 7 March 2017; Ibidem, European Union Training Mission - Somalia, https://eeas.europa.eu/sites/eeas/files/factsheet_eutm_somalia_en.pdf, accessed on 7 March 2017.

[6] European Union External Action Service, Sharing training facilities in the EU in the military field, http:/www.eeas.europa.eu/csdp/structures-instrumentsagencies/trainings/sharing-training-facilities/index_en.htm, accessed on 8 March 2017.

[7] House of Lords, European Defence Capabilities: lessons from the past, signposts from the future, https://www.publications.parliament.uk/pa/ld201012/ldselect/ldeucom/ 292/29202.htm, accessed on 10 March 2017; Marius Pricopi, Integrarea militară europeană, Sibiu, Editura Techno Media, 2014, pp. 246-247. 